\title{
HUBUNGAN LINGKUNGAN BELAJAR DAN MINAT BELAJAR TERHADAP PRESTASI BELAJAR SISWA DI SMP NEGERI 1 CIAWIGEBANG KABUPATEN KUNINGAN
}

\author{
Nur Nur Azijah', ${ }^{1}$ Nasehudin ${ }^{2}$ \\ IAIN Syekh Nurjati Cirebon ${ }^{1,2}$ \\ nurazijah629@gmail.com;nasehudin.iaincrb@gmail.com
}

\begin{abstract}
Abstrak
Berdasarkan observasi di SMP Negeri 1 Ciawigebang bahwa prestasi belajar mata pelajaran IPS siswa kelas VIII SMP Negeri 1 Ciawigebang yang diperoleh siswa dipengaruhi oleh beberapa faktor. Faktor-faktor tersebut berasal dari luar maupun dari dalam diri siswa. Faktor dari luar bisa dari lingkungan belajar siswa selama proses pembelajaran dalam kelas sering tidak kondusif. Faktor dari dalam diri siswa juga mempengaruhi prestasi belajar siswa seperti minat belajar. Siswa kelas VIII SMP Negeri 1 Ciawigebang juga kurang memiliki minat belajar mata pelajaran IPS hal ini dapat diketahui dengan perilaku siswa pada saat kegiatan pelajaran berlangsung siswa cenderung asyik bermain sendiri dari pada memperhatikan penjelasan guru. Penelitian ini bertujuan untuk mengetahui hubungan lingkungan belajar terhadap prestasi belajar siswa, hubungan minat belajar terhadap prestasi belajar siswa, hubungan antara lingkungan belajar dan minat belajar terhadap prestasi belajar siswa mata pelajaran IPS di SMP Negeri 1 Ciawigebang Kabupaten Kuningan. Penelitian dalam skripsi ini menggunakan metode penelitian kuantitatif. Teknik pengumpulan data yang digunakan: observasi, angket, dokumentasi. Teknik analisis data yang digunakan yaitu korelasi product moment pearson dan korelasi ganda. Hasil penelitian ini adalah Tidak terdapat hubungan positif dan signifikan antara lingkungan belajar terhadap prestasi belajar mata pelajaran IPS di SMP Negeri 1 Ciawigebang Kabupaten Kuningan. Hal ini terbukti dari analisis korelasi product moment pada taraf signifikan 5\% yang diperoleh nilai rx1y sebesar 0,086 dan thitung lebih kecil dari ttabel atau 0,086 < 1,670.Tidak terdapat hubungan positif dan signifikan antara minat belajar terhadap prestasi belajar mata pelajaran IPS di SMP Negeri 1 Ciawigebang Kabupaten Kuningan. Hal ini terbukti dari analisis korelasi product moment pada taraf signifikan 5\% yang diperoleh nilai rx2y sebesar 0,113 dan thitung lebih kecil dari ttabel atau 0,113 $<1,670$. Tidak terdapat hubungan yang positif dan signifikan antara lingkungan belajar dan minat belajar secara bersama-sama terhadap prestasi belajar mata pelajaran IPS di SMP Negeri 1 Ciawigebang Kabupaten Kuningan. Hal ini terbukti dari hasil analisis korelasi berganda pada taraf signifikan 5\% yang diperoleh Fhitung $<$ Ftabel atau $0,463<3,148$.
\end{abstract}

Kata kunci : Prestasi Belajar, Lingkungan Belajar, Minat Belajar 


\begin{abstract}
Based on the observation at SMP Negeri 1 Ciawigebang that the learning achievement of IPS subjects students of grade VIII SMP Negeri 1 Ciawigebang obtained by students influenced by several factors. These factors come from outside as well as from within students. External factors can be from the student learning environment during the learning process in the classroom is often not conducive. Factors from within students also affect student achievement such as interest in learning. Grade VIII students of SMP Negeri 1 Ciawigebang also have less interest in learning IPS subject matter this can be known by the behavior of students at the time of the lesson activities students tend to play themselves from the attention of the teacher explanation. This study aims to determine the relationship of learning environment to student achievement, the relationship of learning interest to student achievement, the relationship between the learning environment and the interest of learning toward the achievement of students of IPS subjects in SMP Negeri 1 Ciawigebang Kuningan District. Research in this thesis using quantitative research methods. Data collection techniques used: observation, questionnaires, documentation. Data analysis technique used is product moment correlation pearson and multiple correlation. The result of this research is There is no positive and significant correlation between learning environment on learning achievement of IPS subjects in SMP Negeri 1 Ciawigebang Kuningan Regency. This is evident from the analysis of product moment correlation at a significant level of 5\% obtained rx1y value of 0.086 and $t$ count smaller than ttable or $0.086<1.670$. There is no positive and significant correlation between the interest in learning achievement subjects Social Studies in SMP Negeri 1 Ciawigebang Regency of Kuningan. This is evident from the analysis of product moment correlation at a significant level of 5\% obtained rx2y value of 0.113 and $t$ count smaller than ttable or $0.113<1.670$. There is no positive and significant correlation between the learning environment and the interest of learning together towards the learning achievement of IPS subjects in SMP Negeri 1 Ciawigebang Kuningan District. This is evident from the results of multiple correlation analysis at a significant level of 5\% obtained Fhitung $<$ Ftabel or $0.463<3.148$.
\end{abstract}

Keywords: Learning Achievement, Learning Environment, Interest Learning

\title{
A. PENDAHULUAN
}

\section{Latar Belakang Masalah}

Undang-undang RI Nomor 20 Tahun 2003 Pasal 1 ayat (1) tentang Sistem Pendidikan Nasional menyatakan bahwa pendidikan adalah usaha sadar dan terencana untuk mewujudkan suasana belajar dan proses pembelajaran agar peserta didik secara aktif mengembangkan potensi dirinya untuk mmiliki kekuatan spiritual keagamaan, pengendalian diri, kepribadian, 
kecerdasan, akhlak mulia, serta keterampilan yang diperlukan dirinya, masyarakat, bangsa, dan negara.

Salah satu faktor eksternal dan internal dalam pencapaian prestasi siswa adalah dengan usaha guru dalam menciptakan lingkungan belajar yang kondusif dan membangun minat belajar siswanya. Seperti apapun usaha guru, jika siswanya memberikan respon yang aktif, maka suasananya akan lebih hidup (interaktif).

Berdasarkan observasi di SMP Negeri 1 Ciawigebang bahwa prestasi belajar mata pelajaran IPS siswa kelas VIII SMP Negeri 1 Ciawigebang yang diperoleh siswa dipengaruhi oleh beberapa faktor. Faktor-faktor tersebut berasal dari luar maupun dari dalam diri siswa. Faktor dari luar bisa dari lingkungan belajar siswa, lingkungan belajar siswa kelas VIII SMP Negeri 1 Ciawigebang selama proses pembelajaran dalam kelas sering tidak kondusif. Selain faktor yang berasal dari luar kelas, suasana gaduh, ramai dan tidak kondusif dalam kelas yang diciptakan oleh beberapa siswa membuat lingkungan disekitar siswa kurang mendukung untuk belajar.

Selain faktor lingkungan belajar yang dari luar, faktor dari dalam diri siswa juga mempengaruhi prestasi belajar siswa seperti minat belajar. Siswa kelas VIII SMP Negeri 1 Ciawigebang juga kurang memiliki minat belajar mata pelajaran IPS. Hal ini dapat diketahui dengan perilaku siswa pada saat kegiatan pelajaran berlangsung siswa cenderung asyik bermain sendiri dari pada memperhatikan penjelasan guru.

Prestasi belajar siswa kelas VIII di SMP Negeri 1 Ciawigebang masih cenderung rendah, banyak siswa yang mendapatkan nilai kurang dari KKM. Untuk tercapainya prestasi belajar yang tinggi bukanlah hal yang mudah, karena keberhasilan belajar sangat dipengaruhi oleh banyak faktor yang dapat mempengaruhinya, antara lain adalah faktor internal dan faktor eksternal.

Berdasarkan permasalahan dia atas, prestasi siswa dapat dikatakan belum memenuhi Kriteria Ketuntasan Minimum (KKM), hubungan lingkungan belajar dan minat belajar kurang baik yang mengakibatkan prestasi siswa menurun oleh karena itu sejalan dengan upaya menjawab pokok 
masalah tersebut dia atas, maka penulis tertarik untuk mengadakan penelitian lebih lanjut tentang "HUBUNGAN LINGKUNGAN BELAJAR DAN MINAT BELAJAR DENGAN PRESTASI BELAJAR SISWA MATA PELAJARAN IPS DI SMP NEGERI 1 CIAWIGEBANG KABUPATEN KUNINGAN"

\section{Rumusan Masalah}

Berdasarkan latar belakang masalah diatas, maka masalah dalam penelitian ini dapat dirumuskan sebagai berikut :

a. Bagaimana hubungan lingkungan belajar terhadap prestasi belajar siswa mata pelajaran IPS di SMP Negeri 1 Ciawigebang Kabupaten Kuningan?

b. Bagaimana hubungan minat belajar terhadap prestasi belajar siswa mata pelajaran IPS di SMP Negeri 1 Ciawigebang Kabupaten Kuningan?

c. Bagaimana hubungan lingkungan belajar dan minat belajar terhadap prestasi belajar siswa mata pelajaran IPS di SMP Negeri 1 Ciawigebang Kabupaten Kuningan?

\section{Tujuan Penelitian}

Tujuan pokok peneitian ini adalah untuk menjawab rumusan masalah yang dikemukaakan di atas. Adapun tujuannya adalah sebagai berikut:

a. Mengetahui hubungan lingkungan belajar terhadap prestasi belajar siswa mata pelajaran IPS di SMP Negeri 1 Ciawigebang Kabupaten Kuningan.

b. Mengetahui hubungan minat belajar terhadap prestasi belajar siswa mata pelajaran IPS di SMP Negeri 1 Ciawigebang Kabupaten Kuningan.

c. Mengetahui hubungan lingkungan belajar dan minat belajar terhadap prestasi belajar siswa mata pelajaran IPS di SMP Negeri 1 Ciawigebang Kabupaten Kuningan. 


\section{B. KAJIAN TEORI}

\section{Lingkungan Belajar Siswa}

Lingkungan belajar adalah lingkungan yang secara efektif memberi pengaruh pada proses pendewasaan manusia dalam hidup dan kehidupannya. Secara umum lingkungan belajar di dalamnya juga menunjukan arah, proses, dan interaksi yang mempunyai lintasan tertentu sehingga dapat dipandang sebagai jalur pendidikan yang mencakup jalur pendidikan informal, jalur pendidikan nonformal dan jalur pendidikan formal. Dalam konteks hidup dan kehidupan sosial masyarakat, hubungan ketiga jalur lingkungan belajar yaitu formal, informal, dan nonformal menjadi suatu keharusan dan kenyataan yang memberi rona pada dunia pendidikan, dan harus difahami dengan tepat karena tiap lingkungan tersebut mempunyai dampak yang signifikan bagi pengembangan mutu hidup dan kehidupan manusia, anak-anak kita, siswasiswi kita, murid- murid kita (Suharsaputra, 2011: 155).

Suyrabrata (2006: 233) mengemukakan bahwa lingkungan adalah segala sesuatu yang berbeda di luar individu dimana dalam keseluruhan tingkah lakunya individu tersebut berinteraksi dengan lingkungannya, baik disadari maupun tidak disadari, langsung maupun tidak langsung. Walgito (2010: 146) mengemukakan bahwa lingkungan belajar yang perlu diperhatikan diantaranya tempat belajar, alat-alat untuk belajar, suasana belajar, dan pergaulan.

\section{Minat Belajar Siswa}

Minat (interest) secara sederhana dapat dipahami sebagai kecenderungan dan kegairahan yang tinggi atau keinginan besar terhadap sesuatu hal (Syah, 2016: 133). Istilah minat merupakan terminologi aspek kepribadian, yang menggambarkan adanya kemauan, dorongan (force) yang timbul dari dalam diri individu untuk memilih objek lain yang sejenis. Objek dari minat bisa berbagai macam, baik makhluk hidup, aktivitas, benda mati, pekerjaan, dan lain-lain.

Minat adalah perasaan yang ingin tahu, mempelajari, mengagumi atau memiliki sesuatu (Djaali, 2004: 122). Sedangkan Slameto (2015: 180) mengartikan minat adalah suatu rasa lebih suka dan rasa ketertarikan pada 
suatu hal atau aktivitas, tanpa ada yang menyuruh. Minat pada dasarnya adalah penerimaan akan suatu hubungan antara diri sendiri dengan sesuatu di luar diri.

\section{Prestasi Belajar Siswa}

Istilah prestasi belajar terdiri dari dua suku kata, yaitu prestasi dan belajar. Istilah prestasi ini didefinisikan sebagai hasil yang telah di capai (Wahab, 2016: 242). Prestasi belajar adalah hasil yang diperoleh seseorang setelah menempuh kegiatan belajar, sedangkan belajar pada hakekatnya merupakan usaha sadar yang dilakukan seseorang untuk memenuhi kebutuhannya. Setiap kegiatan belajar dilakukan peserta didik akan menghasilkan prestasi belajar, berupa perubahan-perubahan perilaku, yang oleh Bloom dan kawan-kawan dikelompokan ke dalam kawasan kognitif, afektif, dan psikomotorik. Perubahan perilaku sebagai hasil belajar mempunyai ciri-ciri tertentu, (Mulyasa, 2014: 189).

Tu'u (2004: 75) menyatakan bahwa prestasi belajar adalah hasil yang dicapai seseorang ketika mengerjakan tugas atau kegiatan tertentu. Prestasi belajar juga merupakan penguasaan pengetahuan atau keterampilan yang dikembangkan oleh mata pelajaran. Biasanya, prestasi belajar ditunjukan dengan nilai tes atau nilai berupa angka yang diberikan oleh guru.

\section{Hakikat Ilmu Pengetahuan Sosial}

Undang-undang Nomer 20 tahun 2003 tentang Sistem Pendidikan Nasional pasal 37, dijelaskan bahwa Ilmu Pengetahuan Sosial (IPS) merupakan bahan kajian yang wajib dimuat dalam kurikulum pendidikan dasar dan menengah yang antara lain mencakup ilmu bumi, sejarah, ekonomi, kesehatan, dan lain sebagainya yang dimaksudkan untuk mengembangkan pengetahuan, pemahaman, dan kemampuan analisis peserta didik terhadap kondisi sosial masyarakat. Ilmu Pengetahuan Sosial sebagai bahan kajian merupakan subject matter yang dapat dikemas menjadi satu atau beberapa mata pelajaran atau diintegrasikan dengan bahan kajian lain sesuai dengan kebutuhan pendidikan. IPS merupakan integrasi disiplin ilmuilmu sosial (Sumantri, 2001: 73). 


\section{Kajian Penelitian Relevan}

Hasil Penelitian dari Isnaeni pada tahun 2013 yang berjudul “Hubungan Antara Lingkungan Belajar dengan Keberhasilan Belajar Siswa Pada Mata Pelajaran IPS (Ekonomi) Kelas VII di SMP Negeri Depok Kabupaten Cirebon” Skripsi FITK IAIN Syekh Nurjati Cirebon.

a. Perbedaan Penelitian

Dari penelitian di atas terdapat perbedaan penelitian yaitu: terdapat perbedaan judul, penelitian terdahulu hanya meneliti tentang hubungan lingkungan belajar dengan keberhasilan belajar saja, sedangkan penulis akan meneliti tentang hubungan lingkungan belajar dan minat belajar dengan prestasi belajar siswa dan juga perbedaan pada tahun penelitian.

b. Persamaan Penelitian

Dari penelitian diatas, terdapat persamaan antara lain yaitu: sama- sama meneliti hubungan, terdapat persamaan objek penelitian yaitu sekolah menengah pertama (SMP) dan terdapat persamaan dalam variabel $\mathrm{X}$ yaitu tentang lingkungan belajar siswa.

\section{METODE PENELITIAN}

\section{Jenis Penelitian}

Penelitian ini merupakan penelitian korelasional product moment. Korelasi adalah analisis yang menyatakan hubungan antara dua variabel atau lebih.

Pendekatan dalam penelitian ini adalah kuantitatif. Pendekatan kuantitatif digunakan untuk mengukur variabel bebas dan variabel terikat dengan menggunakan angka-angka yang diolah melalui analisis statistik. Metode penelitian kuantitatif dapat diartikan sebagai metode yang berlandaskan filsafat positivisme, digunakan untuk meneliti pada populasi atau sampel tertentu, teknik pengambilan sampel pada umumnya dilakukan secara random, pengumpulan data menggunakan instrument penelitian analisis data bersifat ststistik dengan tujuan untuk menguji hipotesis yang telah ditetapkan. (Sugiyono, 2016: 14). 


\section{Lokasi dan Waktu Penelitian}

Penelitian ini dilaksanakan di SMP Negeri 1 Ciawigebang Kabupaten Kuningan.Waktu pelaksanaan penelitian dari bulan November 2017 sampai Februari 2018.

\section{Populasi dan Sampel}

\section{a. Populasi}

Populasi dalam penelitian ini adalah seluruh siswa kelas VIII SMP Negeri 1 Ciawigebang yang berjumlah 318 siswa.

\section{b. Sampel}

Berdasarkan ketentuan tersebut, penulis mengambil sampel 20\% x $318=63,6$ dibulatkan menjadi 64, dimana dari ke 9 kelas tersebut penulis mengambil sampel dari masing-masing kelas sebanyak 7 siswa, kelas VIII-A 7 siswa, VIII-B 7 siswa, VIII-C 7 siswa, VIII-D 7 siswa, VIIIE 7 siswa, VIII-F 7 siswa, VIII-G 7 siswa, VIII-H 8 siswa, VIII-I 7 siswa.

\section{Variabel Penelitian}

Adapun variabel-variabel yang digunakan dalam penelitian ini adalah variabel bebas atau independent variable terdiri dari dua variabel (X1) adalah lingkungan belajar dan (X2) adalah minat belajar dan variabel terikat dependent variable (Y) adalah prestasi belajar siswa.

\section{Teknik Instrumen Pengumpulan Data}

a. Observasi

Teknik ini dilakukan dengan mengadakan pengamatan langsung ke objek penelitian yaitu dengan penelitian mengamati sejauh mana lingkungan belajar, minat belajar dan prestasi belajar siswa kelas VIII di SMP Negeri 1 Ciawigebang.

b. Dokumentasi

Menurut Arikunto (2006: 158) menyatakan bahwa dokumentasi adalah mencari dan mengumpulkan data mengenai hal-hal yang berupa catatan, transkip, rapot, buku, surat kabar, majalah, notulen, agenda dan sebagainya. Jadi dokumentasi adalah mencari data-data tentang prestasi belajar siswa kelas VIII di SMP Negeri 1 Ciawigebang. 
c. Angket atau Kuesioner

Berdasarkan uraian di atas bahwa angket ini digunakan untuk memperoleh data variabel (X) yaitu lingkungan belajar dan minat belajar. Data tentang lingkungan belajar dan minat belaja diperoleh oleh hasil pengisian angket yang diisi oleh responden.

\section{Validitas dan Reliabilitas Instrumen}

a. Uji Validitas

Menurut Arikunto (2006: 168) uji validitas adalah suatu ukuran yang menunjukan tingkat-tingkat kevalidan atau kesahihan suatu instrumen. Suatu instrumen yang valid atau sahih memiliki tingkat kevalidan yang tinggi.

b. Uji Reliabilitas

Menurut Arikunto (2006: 178) bahwa reabilitas menunjuk pada satu pengertian bahwa sesuatu cukup dapat dipercaya untuk digunakan sebagai alat pengumpul data karena instrumen tersebut adalah baik.

\section{Teknik Analisis Data}

a. Skala Prosentase

Pengumpulan data yang dilakukan dalam uji prosentase ini yaitu dengan menyebarkan angket kepada siswa yang sudah menjadi sampel penelitian.

b. Uji Normalitas

Setelah angket diketahui validitas dan realibilitas, angket tersebut kemudian disebarkan kepada sampel penelitian. Kemudian dari data masing-masing variabel yang diperoleh diuji normalitasnya terlebih dahulu untuk mengetahui apakah penyebaran data kedua variabel tersebut normal atau tidak.

c. Uji Homogenitas

Uji homogenitas digunakan untuk mengetahui apakah beberapa varian populasi adalah sama atau tidak (Priyatno, 2008: 31). 


\section{d. Pengujian Hipotesis}

1) Analisis Korelasi Sederhana

Analisis korelasi sederhana (Bivariate Correlation) digunakan untuk mengetahui keeratan hubungan antara dua variabel dan untuk mengetahui arah hubungan yang terjadi. Koefisien korelasi sederhana menunjukan seberapa besar hubungan yang terjadi antara dua variabel.

2) Analisis Korelasi Berganda

Analisis korelasi berganda merupakan pengembangan dari analisis korelasi sederhana. Kegunaannya yaitu untuk meramalkan nilai variabel terikat (Y) apabila variabel bebasnya dua atau lebih. (Somantri dan Sambas, 2006: 250).

3) Analisis Determinasi

Perhitungan ini dimanfaatkan untuk mengetahui seberapa besar kontribusi variabel $\mathrm{X}$ dalam menjelaskan keragaman variabel Y.

\section{HASIL PENELITIAN DAN PEMBAHASAN}

Berdasarkan penelitian tentang hubungan antara lingkungan belajar dengan prestasi belajar mata pelajaran IPS di SMP Negeri 1 Ciawigebang Kabupaten Kuningan hasil pengisian angket secara keseluruhan pada variabel lingkungan belajar menunjukkan bahwa tingkat lingkungan belajar siswa Kelas VIII di SMP Negeri 1 Ciawigebang pada Mata Pelajaran IPS tahun 2017/2018 adalah 35.22\% $+50.72 \%=85,94 \%$. Angka ini berada diantara 75\% - 100\% yang dikategorikan baik.

Hasil penelitian ini menunjukkan tidak terdapat hubungan antara lingkungan belajar terhadap prestasi belajar mata palajaran IPS. Penghitungan dengan korelasi sederhana diperoleh nilai koefisien korelasi $\left(\mathrm{r}_{\mathrm{x} 1 \mathrm{y}}\right)$ sebesar

0,086 Hal ini menunjukan bahwa terdapat hubungan yang sangat rendah dan positif antara lingkungan belajar terhadap prestasi belajar mata pelajaran IPS. Hasil penghitungan dengan uji t diperoleh nilai $t_{\text {hitung }}$ sebesar 0,681 apabila dibandingkan dengan nilai tabel pada taraf signifikansi $\alpha=5 \%$ dengan derajat kebebasan df $n-2$ atau 64-2 = 62 sebesar 1,670, maka $t_{\text {hitung }}$ $<t_{\text {tabel }}(0,681<1,670)$. Hal ini menunjukan bahwa tidak terdapat hubungan 
yang signifikan antara lingkungan belajar dan prestasi belajar mata pelajaran IPS.

Berdasarkan pemaparan tersebut, ternyata tidak terdapat hubungan yang signifikan antara lingkungan belajar terhadap prestasi belajar mata pelajaran IPS di SMP Negeri 1 Ciawigebang ini disebabkan ada faktor lain yang lebih kuat dalam mempengaruhi prestasi belajar siswa serta pada saat pengisian angket siswa kelas VIII SMP Negeri 1 Ciawigebang banyak yang mengisi angket dengan sembarangan dan tidak sesuai yang diharapkan dan penelitian ini tidak sampai tuntas meneliti faktor lain yang lebih kuat dalam mempengaruhi prestasi belajar siswa kelas VIII di SMP Negeri 1 Ciawigebang.

Berdasarkan penelitian tentang hubungan antara minat belajar dengan prestasi belajar mata pelajaran IPS di SMP Negeri 1 Ciawigebang Kabupaten Kuningan hasil pengisian angket secara keseluruhan pada variabel minat belajar menunjukan bahwa tingkat minat belajar di SMP Negeri 1 Ciawigebang Kabupaten Kuningan kelas VIII pada Mata Pelajaran IPS tahun $2017 / 2018$ adalah 23,88\% $+58,37 \%=82,25 \%$. Angka ini berada diantara $75 \%$ - 100\% yang dikategorikan baik.

Hasil penelitian ini menunjukkan tidak terdapat hubungan positif antara minat belajar terhadap prestasi belajar mata palajaran IPS. Penghitungan dengan korelasi sederhana diperoleh nilai koefisien korelasi $\left(\mathrm{r}_{\mathrm{x} 2 \mathrm{y}}\right)$ sebesar 0,113. Hal ini menunjukan bahwa terjadi hubungan yang sangat rendah dan positif antara minat belajar terhadap prestasi belajar. Hasil penghitungan dengan uji t diperoleh nilai thitung sebesar 0,893 apabila dibandingkan dengan nilai $\mathrm{t}_{\text {tabel }}$ pada taraf signifikansi $5 \alpha=5 \%$ dengan derajat kebebasan $\mathrm{df} \mathrm{n}-2$ atau $64-2=62$ sebesar 1,670 maka thitung $<t_{\text {tabel }}(0,893<1,670)$. Hal ini menunjukan bahwa tidak terdapat hubungan yang signifikan antara minat belajar dan prestasi belajar mata pelajaran IPS.

Berdasarkan pemaparan tersebut ternyata tidak terdapat hubungan yang signifikan antara minat belajar terhadap prestasi belajar mata pelajaran IPS di SMP Negeri 1 Ciawigebang ini disebabkan ada faktor lain yang lebih kuat dalam mempengaruhi prestasi belajar siswa serta pada saat pengisian angket 
siswa kelas VIII SMP Negeri 1 Ciawigebang banyak yang mengisi angket dengan sembarangan dan tidak sesuai yang diharapkan dan penelitian ini tidak sampai tuntas meneliti faktor lain yang lebih kuat dalam mempengaruhi prestasi belajar siswa kelas VIII di SMP Negeri 1 Ciawigebang.

Perdasarkan penelitian tentang hubungan lingkungan belajar dan minat belajar terhadap prestasi belajar siswa mata pelajaran IPS di SMP Negeri 1 Ciawigebang Kabupaten Kuningan hasil pengujian hipotesis ketiga menunjukan bahwa tidak terdapat hubungan yang signifikan antara lingkungan belajar dan minat belajar secara bersama-sama terhadap prestasi belajar mata pelajaran IPS. Berdasarkan hasil perhitungan korelasi ganda, diperoleh nilai koefisien korelasi $\left(\mathrm{R}_{\mathrm{yx} 1 \times 2}\right)$ positif sebesar 0,122 sehingga lingkungan belajar dan minat belajar secara bersama-sama memiliki tidak terdapat hubungan dengan prestasi belajar mata pelajaran IPS. Setelah dilakukan uji $\mathrm{F}$ diperoleh $\mathrm{F}_{\text {hitung }}$ sebesar 0,463 dan nilai $\mathrm{F}_{\text {tabel }}$ pada taraf signifikansi 5\% sebesar 3,148 hal ini menunjukan bahwa $F_{\text {hitung }}<F_{\text {tabel }}$ sehingga lingkungan belajar dan minat belajar secara bersama-sama terhadap prestasi belajar mata pelajaran IPS tidak terdapat hubungan yang signifikan ini disebabkan ada faktor lain yang lebih kuat dalam mempengaruhi prestasi belajar siswa serta pada saat pengisian angket siswa kelas VIII SMP Negeri 1 Ciawigebang banyak yang mengisi angket dengan sembarangan dan tidak sesuai yang diharapkan dan penelitian ini tidak sampai tuntas meneliti faktor lain yang lebih kuat dalam mempengaruhi prestasi belajar siswa kelas VIII di SMP Negeri 1 Ciawigebang.

\section{E. KESIMPULAN DAN SARAN}

1. Kesimpulan

Berdasarkan hasil analisis dan penelitian, kesimpulan penelitian ini adalah:

a. Tidak terdapat hubungan positif dan signifikan antara lingkungan belajar terhadap prestasi belajar mata pelajaran IPS di SMP Negeri 1 Ciawigebang Kabupaten Kuningan. Hal ini terbukti dari analisis korelasi 
product moment pada taraf signifikan $5 \%$ yang diperoleh nilai $\mathrm{r}_{\mathrm{x} 1 \mathrm{y}}$ sebesar 0,086 dan $t_{\text {hitung }}$ lebih kecil dari $t_{\text {tabel }}$ atau $0,086<1,670$.

b. Tidak terdapat hubungan positif dan signifikan antara minat belajar terhadap prestasi belajar mata pelajaran IPS di SMP Negeri 1 Ciawigebang Kabupaten Kuningan. Hal ini terbukti dari analisis korelasi product moment pada taraf signifikan 5\% yang diperoleh nilai $\mathrm{r}_{\mathrm{x} 2 \mathrm{y}}$ sebesar 0,113 dan $\mathrm{t}_{\text {hitung }}$ lebih kecil dari $t_{\text {tabel }}$ atau 0,113 $<1,670$.

c. Tidak terdapat hubungan yang positif dan signifikan antara lingkungan belajar dan minat belajar secara bersama-sama terhadap prestasi belajar mata pelajaran IPS di SMP Negeri 1 Ciawigebang Kabupaten Kuningan. Hal ini terbukti dari hasil analisis korelasi berganda pada taraf signifikan $5 \%$ yang diperoleh $\mathrm{F}_{\text {hitung }}<\mathrm{F}_{\text {tabel }}$ atau $0,463<3,148$.

2. Saran

Berdasarkan hasil pembahasan dan kesimpulan penelitian ini, beberapa saran yang diberikan adalah:

a. Siswa disarankan untuk berusaha memilih suasana dan kondisi yang mendukung untuk belajar.

b. Siswa disarankan untuk berupaya menumbuhkan rasa suka, tertarik, dan memberikan perhatian yang besar dalam belajar.

c. Guru disarankan untuk berupaya menciptakan lingkungan belajr yang kondusif di dalam kelas selama proses pembelajaran berlangsung.

d. Guru disarankan agar menyampaikan materi pelajaran IPS dengan metode pembelajaran yang variatif supaya siswa mempunyai minat yang lebih tinggi untuk Ilmu Pengetahuan Sosial.

\section{DAFTAR PUSTAKA}

Arikunto, Suharsimi. 2006. Prosedur Penelitian Suatu Pendekatan Praktek. Yogyakarta: Rineka Cipta.

. 2014. Prosedur Penelitian Suatu Pendekatan Praktek. Yogyakarta: Rineka Cipta. 
Djaali. 2004. Psikologi Pendidikan. Jakarta: Bumi Aksara.

Mulyasa. 2014. Pengembangan dan Implementasi Kurikulum 2013. Bandung: Remaja Rosdakarya.

Priyatno, Duwi. 2008. Mandiri Belajar SPSS. Yogyakarta: Mediakom.

Slameto. 2013. Belajar dan Faktor-faktor yang Mempengaruhi. Jakarta: Rineka Cipta.

Somantri, Ating dan Sambas Ali Muhidin. 2006. Aplikasi Statistika dalam Penelitian. Bandung: Pustaka Setia.

Suharsaputra, Uhar. 2011. Menjadi Guru Berkarakter. Yogyakarta: Paramitra Publishing.

Sugiyono. 2016. Metode Penelitian Kuantitatif, Kualitatif dan R\&D.Bandung: Alfabeta.

Sumantri, Norman. 2001. Menggagas Pembaharuan Pendidikan IPS. Bandung: Remaja Rosdakarya.

Suryabrata, Sumandi. 2006. Psikologi Pendidikan. Jakarta: Raja Garfindo Persada.

Syah, Muhibin. 2017. Psikologi Pendidikan dengan Pendekatan Baru. Jakarta: Remaja Rosdakarya.

Tu'u, Tulus. 2004. Peran Disiplin Pada Perilaku dan Prestasi Siswa. Jakarta: Grasindo.

UU Sisdiknas No. 20 Tahun 2003. Sistem Pendidikan Nasional.

Wahab, Rohmalina. 2016. Psikologi Belajar. Jakarta: Rajawali Pers.

Walgito, Bimo. 2010. Psikologi Sosial. Yogyakarta: Andi Offset.

Isnaeni. 2013. Hubungan Antara Lingkungan Belajar dengan Keberhasilan Belajar Siswa Pada Mata Pelajaran IPS (Ekonomi) Kelas VIII di SMP Negeri Depok Kabupaten Cirebon. Skripsi Fakultas Ilmu Tarbiyah dan Keguruan IAIN Syekh Nurjati Cirebon. http://respository.syekhnurjati.ac.id/875/.diakses.18/01/2017.pukul.20:00. WIB. 